\title{
Honey bee (Apis mellifera) sperm competition in vitro - two are no less viable than one*
}

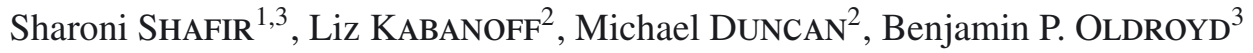 \\ ${ }^{1}$ B. Triwaks Bee Research Center, Department of Entomology, The Robert H. Smith Faculty of Agriculture, \\ Food, and Environment, The Hebrew University of Jerusalem, Israel \\ ${ }^{2}$ Centre for Plant and Food Science, University of Western Sydney, Penrith South DC, 1797, NSW, Australia \\ ${ }^{3}$ Behaviour and Genetics of Social Insects Lab, School of Biological Sciences A12, University of Sydney, \\ Sydney, NSW 2006, Australia
}

Received 15 September 2008 - Revised 25 January 2009 - Accepted 30 January 2009

\begin{abstract}
Sperm competition is the competition between sperm of different males for the fertilization of an ovum. Queen honey bees mate with many males over a short period, establishing ideal conditions in which sperm competition might occur. One hypothesized mechanism by which sperm competition may occur is via sperm incapacitation (SI), which involves the killing and/or inhibition of function of sperm from one male by sperm (or seminal fluid) of another male. However, there is very little empirical support for SI in any animal. We tested whether reported increases in mortality of honey bee spermatozoa when semen from several drones is mixed can be attributed to SI. We found that when the collection method involves minimal manipulation, sperm viability is not reduced in samples of mixed semen from two drones relative to those of a single drone. Our results do not support the existence of SI by killing of sperm (during early encounter in vitro) between semen from unrelated drones, and suggest that reported reductions in sperm viability in mixed samples arise from mechanical damage during semen collection.
\end{abstract}

\section{Apis mellifera / sperm viability / sperm competition / sperm incapacitation / polyandry}

\section{INTRODUCTION}

During her first days as an adult, a queen honey bee (Apis mellifera L.) undertakes one or two mating flights during which she mates with upwards of 10 drones (Winston, 1987; Palmer and Oldroyd, 2000; Tarpy et al., 2004). Semen from the drones mixes in the queen's median and lateral oviducts (Snodgrass, 1956; Koeniger and Koeniger, 1991; Baer, 2005) and over the next 24 hours, about $10 \%$ of the spermatozoa are eventually transferred to the spermatheca (Woyke, 1983). Stored spermatozoa are used to fertilize eggs for the duration of the queen's life, which can be as many as 45 years.

Corresponding author: S. Shafir, shafir@agri.huji.ac.il

* Manuscript editor: Klaus Hartfelder
During the sperm transfer process, more than $90 \%$ of the sperm are lost after flowing back and expelled through the vagina (Koeniger and Koeniger, 1991). Such a mating system should be conducive to the evolution of competition between the sperm from different males because the fitness premium for transfer to the spermatheca is large (Parker, 1970, 1998; Baer, 2005; Boomsma et al., 2005). Thus the honey bee is an ideal experimental organism in which to seek evidence for sperm competition.

Evidence for sperm competition can be tested empirically by calculating patriline frequencies in the offspring of multiply mated queens. Several studies have found fluctuations in patriline frequencies over time, but without consistent increases in frequency of the paternity of particular drones (Kerr et al., 1980; Haberl and Tautz, 1998; Franck et al., 1999) and have therefore concluded that there 
is no evidence for sperm competition. In contrast, Harbo (1990) concluded that when groups of queens were instrumentally inseminated with semen containing various ratios of genetically marked and unmarked sperm, sperm competition was responsible for unidirectional changes in the frequencies of certain patrilines. Schlüns et al. (2004) found that in instrumentally inseminated queens, patriline frequency is related to semen volume in a nonlinear manner, with males with large semen volume being consistently over-represented in offspring. Franck et al. (2002) found consistent differences between drones in paternity frequencies over time. This was interpreted as evidence for sperm competition, though the mechanism was not clear.

Evidence for sperm competition can also be provided by evaluation of semen distributions within the queen's spermatheca. Moritz (1986) failed to find evidence for sperm competition within the spermatheca of queens instrumentally inseminated with semen of several drones diluted in saline solution. However, Woyciechowski and Krol (1996) suspected that sperm competition occurs earlier, in the queen's oviducts, and that diluting the sperm may affect its ability to compete, for example by affecting its motility (Werner and Simmons, 2008).

Sperm competition encompasses a variety of mechanisms (Simmons, 2001; Snook, 2005; Pizzari and Foster, 2008). Sperm loading occurs when males increase the number of sperm in their ejaculate relative to sperm from rival males. Sperm flushing is the removal of existing sperm in the female genital tract by sperm deposited by a second or subsequent male in the mating order. Similarly, sperm repositioning occurs when sperm of a subsequent male displaces resident sperm away from the storage organ or the fertilization site. Sperm stratification is the occupation by sperm of an advantaged position for fertilization, for example as a result of mating order. Sperm incapacitation (SI) involves the killing and/or inhibition of function of sperm from one male by sperm (or seminal fluid) of another male (Silberglied et al., 1984).

Woyciechowski and Krol (1996) counted the number of spermatozoa in the honey bee queen spermatheca $48 \mathrm{~h}$ after instrumental insemination with an equal volume of undiluted sperm from one drone or several related or unrelated drones. They found no evidence for SI within the oviducts, as the number of spermatozoa that reached the spermatheca did not differ between treatments. However, Woyciechowski and Krol conclude that their study cannot refute the existence of intraoviductal sperm competition because they did not test the proportions of sperm of individual drones in the spermatheca, nor did they test variability in sperm viability between drones.

Woyciechowski and Krol's study was constrained by the amount of sperm in a single drone's ejaculate, forcing them to inseminate queens with an unnaturally small sperm volume. This experimental constraint may have weakened any effect of sperm competition. For example, Collins (2004) found a ca. 50\% reduction in sperm viability in mixtures of sperm from several drones relative to samples from single drones. Although Collins attributed this reduction to physical damage during sperm collection and mixing, SI may have also contributed to a reduction in viability, providing the strongest evidence yet for SI.

Here, we determine whether SI occurs in the mixed ejaculates of male honey bees. Such a mechanism would be an effective mechanism of sperm competition, since sperm quality and viability is an important determinant of paternity success (Garcia-Gonzalez and Simmons, 2005). Overall, despite the theoretical appeal of the SI hypothesis, there is still only little support for it (Pizzari and Foster, 2008). SI has been suggested to occur in Lepidoptera (Silberglied et al., 1984), some snails (Buckland-Nicks, 1998) and Drosophila (Price et al., 1999). To test this hypothesis, we compared in vitro sperm viability from single drones and a mixture of two drones, in an assay with minimal physical manipulation.

\section{MATERIALS AND METHODS}

\subsection{Drones}

To obtain drones of equal sexual maturity, we added an empty drone comb into each of six honey 
bee (Apis mellifera) colonies and caged the queens on them for three days. After 24 days, when the drones were ready to emerge, the combs with sealed brood were caged and placed in an incubator at $35^{\circ} \mathrm{C}$. All the drones that emerged within a single day were marked with a drop of paint on their thorax, which identified their colony of origin. Marked drones were then co-fostered in a single colony.

\subsection{Semen collection}

We used standard techniques (Laidlaw and Page, 1997) to collect semen from the drones on two days, when they were 15 and 18 days old. We used a Mackensen syringe to collect semen into glass insemination tips (Peter Schley, Bee-breeding equipment, Lich, Germany). The insemination diluent comprised $1 \% \mathrm{NaCl}$ and $0.25 \%$ dihydrostreptomycin (Harbo, 1990). On both days, we loaded half the tips with semen from a single drone and half the tips with semen from two unrelated drones.

We wished to ensure that the single and double drone samples experienced similar levels of handling. For the single drone samples we drew the semen into the tip and then immediately ran it back out onto the drone genitalia before collecting it again. For the two-drone samples, after collecting semen from one drone we ran the sample onto the semen on the genitalia of the second drone, and then collected the mixture of the two drones into the tip. After collecting each sample we drew c.a. $15 \mu \mathrm{L}$ of diluent into the tip with a $5 \mathrm{~mm}$ air bubble between the semen and the diluent. We also left diluent in the top part of the tip, separated from the semen by an air bubble. This prevented the samples from drying out during storage.

Depending on the availability of mature drones, we collected drones for single- or two-drone samples. We collected 4-10 single-drone samples from each of five colonies, and 2-6 two-drone samples from each of seven combinations of drone source colonies. We stored the samples in the glass tips for four days in an incubator at $25^{\circ} \mathrm{C}$. To further reduce desiccation of the samples, we placed an open vessel of water in the incubator to maintain saturated humidity.

\subsection{Assessing spermatozoa viability}

After storage the viability of spermatozoa was determined by the method of Collins and Donoghue
(1999). Each sample was mixed with $200 \mu \mathrm{L}$ Tris buffer (Williams and Harbo, 1982) (0.05 M Tris buffer, $\mathrm{pH} 8.7$, supplemented with $1.1 \%$ sodium chloride, $0.1 \%$ glucose, $0.01 \% \mathrm{~A}(+)$ arginine-HCL and $0.01 \% \mathrm{~L}(+)$ lysine). To avoid additional manipulations and due to the small sample volumes, we did not control for sample volume. Possibly, the two-drone samples had greater volumes than the single-drone ones and were therefore slightly less dilute after being mixed with Tris buffer. However, since diluting sperm would reduce its viability, any such effect would act in the opposite direction to our hypothesis of reduced viability in the two-drone samples.

The diluted semen was stained with SYBR-14 and propidium iodide (Live/dead sperm viability kit, Molecular Probes, Eugene, OR). We diluted the SYBR 14 and the propidium iodide stock solutions 1:50 and 1:20, respectively, in Tris buffer. SYBR 14 is a membrane-permeant stain that colours nucleic acid green in both live and dead sperm. Propidium iodide is a red stain that only enters damaged (dead) cells and replaces the SYBR 14 stain. Thus, these stains dye live cells green and dead cells red.

We placed $5 \mu \mathrm{L}$ of a sample on a microscope slide and covered it with a cover slip. We examined each slide using a 200X magnification on an Olympus BX60 fluorescent microscope, and took digital photos of at least ten fields of view of each slide. The photos were analysed blindly as to the origin of the sample using imageJ software (Abramoff et al., 2004). We used a cell counter plugin to count the number of green and red cells in each photo (http:// rsb.info.nih.gov/ij/plugins/cell-counter.html). Cells that were dyed partially red and partially green were counted separately, but were later pooled together with the red cells, since these are dying cells. We counted all cells on each photo, summing up the counts from photos of a particular sample, until at least 100 cells had been counted. The mean ( \pm SD) number of cells counted per sample was $114 \pm 16$, and required a mean of $5.5 \pm 2.8$ fields of view.

\subsection{Statistics}

We calculated sperm percent viability as the number of live (green-dyed) cells divided by the total number of cells counted in each sample. We compared viability of single- and two-drone samples using ANOVA of arcsin square-root transformed proportions, using JMP 6 software (SAS Institute). The main factor was treatment 


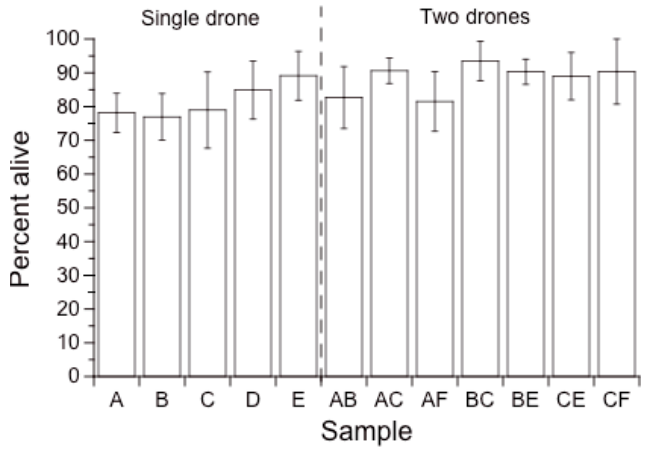

Figure 1. Mean $( \pm$ SE) percent live sperm in samples of single drones or of two drones from different colonies mixed together. Drones were from six colonies (A-F).

(single-drone or two-drone), and we included a term identifying the drone-mother colony (or colony combination), nested within treatment.

\section{RESULTS}

Sperm viability was high in both singleand two-drone samples (Fig. 1), with overall mean $( \pm$ SE, $n)$ viability of $81 \%( \pm 0.03$, $31)$ and $88 \%( \pm 0.02,31)$, respectively. The identity of the colony (or colony combination) did not have a significant effect on viability $\left(\mathrm{F}_{10,50}=0.59, P=0.81\right)$, and the effect of treatment (single- or two-drones) was also not significant $\left(\mathrm{F}_{1,50}=2.29, P=0.14\right)$. The power of our analysis to detect a significant (alpha $=$ 0.05 ) treatment effect was 0.32 . However, the trend in our data was of higher viability of the two-drone samples relative to one-drone samples - the opposite to what is expected under the SI hypothesis.

\section{DISCUSSION}

Unlike Collins (2004), we did not find significant differences in sperm viability between sperm of single drones and mixtures of sperm from two unrelated drones. We used a technique that caused minimal physical manipulation, and standardized manipulation between the two treatments. The high viability of sperm in our study is typical for honey bees (Hunter and Birkhead, 2002), and suggests that sperm were not seriously damaged by our manipulations. Thus, our results support the interpretation of Collins, that the differences in her study were due to damage caused by greater physical manipulation of the multi-drone samples relative to single drone samples.

Our results show that sperm (or other components of the ejaculate) from unrelated drones do not kill one another upon encounter. It is possible that SI occurs at other times such as during transfer to the spermatheca, or within the spermatheca itself. Lodesani et al. (2004) found a significantly greater percent of dead spermatozoa in the spermathecae of 24-month old queens relative to 2- and 12month old queens. Whether this is due to SI or other causes of senescence remains to be tested. It is also possible that other mechanisms of sperm competition exist, for example competition during the fertilization process (Baer, 2005), or within the egg itself.

Our study was conducted in vitro. Thus, if SI depends on environmental factors within the queen's genital tract (Werner and Simmons, 2008), our assay would not have detected it.

The productivity of a honey bee queen is limited by the amount of viable sperm she can store in the spermatheca over an extended time (Kraus et al., 2004). Furthermore, it is in the queen's interest to maintain a genetically diverse pool of sperm in her spermatheca. Genetically diverse colonies are less susceptible to diseases (Tarpy and Seeley, 2006; Seeley and Tarpy, 2007), are better able to thermoregulate (Jones et al., 2004), and have higher productivity and fitness (Mattila and Seeley, 2007). The absence of SI in honey bees would be consistent with female control ruling over male interests.

\section{ACKNOWLEDGEMENTS}

We thank Boaz Yuval for discussion and input, and two anonymous referees for valuable comments. SS thanks the Behaviour and Genetics of Social Insects Lab for hosting him during his sabbatical at the University of Sydney. The experiments comply with the current laws of Australia. 
Compétition spermatique in vitro chez l'abeille domestique (Apis mellifera) : le sperme de deux mâles n'est pas moins viable que celui d'un seul.

\section{Apis mellifera / sperme / viabilité / qualité /} concurrence / polyandrie

Zusammenfassung - In vitro Test zur Spermakonkurrenz bei der Honigbiene (Apis mellifera) - Sperma zweier Drohnen ist nicht weniger lebensfähig als das eines einzelnen. Eine Bienenkönigin (Apis mellifera) paart sich mit mehr als zehn Drohnen. Von diesem Spermagemisch gelangen allerdings nur $10 \%$ in die Spermatheka, während der Rest wieder ausgeschieden wird. Ein solches Paarungssystem sollte die Evolution einer Spermakonkurrenz begünstigen, d.h. die Konkurrenz des Spermas verschiedener Männchen um die Besamung eines Eies. Eine der hypothetischen Möglichkeiten der Spermakonkurrenz ist die Spermaqualitätsminderung [sperm incapacitation (SI)], bei der die Samenflüssigkeit eines Männchens die Lebenfähigkeit oder die Funktion des Spermas eines anderen negativ beeinflussen kann. Für die SI-Hypothese gibt es für Tiere allgemein allerdings nur wenig empirische Daten. Wir testeten, ob es zu einer Zunahme der Spermienmortalität kommen könnte, wenn das Sperma mehrere Drohnen gemischt wird. Hierzu benutzten wir eine Mackensen'sche Spritze, um Sperma von Drohnen in Glasskapillaren aufzusaugen. Die Hälfte der Proben enthielt Sperma von Einzeldrohnen, während die andere Hälfte eine Mischung des Spermas zweier Drohnen darstellte. Nach vier Tagen untersuchten wir die Lebensfähigkeit der Spermien mittels eines lebend/tot Spermaviabilitätstestverfahrens, bei dem lebende Zellen grün und tote Zellen rot gefärbt erscheinen. Wir fanden, dass bei einer Sammelmethode, die die Spermamanipulation möglichst gering hält, die Lebensfähigkeit in Mischproben des Spermas von zwei Drohnen nicht geringer ist als in Einzelspermaproben. Unsere Ergebnisse geben also keinen Hinweis auf die Existenz einer SI-bedingten Spermaqualitätsminderung (zumindest nicht unter kurzzeitigen in vitro Testbedingungen) für Sperma nichtverwandter Drohnen.

\section{Apis mellifera / Spermienlebensfähigkeit / Sper- makonkurrenz / Spermaqualitätsminderung / Mehrfachpaarung}

\section{REFERENCES}

Abramoff M.D., Magelhaes P.J., Ram S.J. (2004) Image processing with imageJ, Biophotonics Int. $11,36-42$.
Baer B. (2005) Sexual selection in Apis bees, Apidologie 36, 187-200.

Boomsma J.J., Baer B., Heinze J. (2005) The evolution of male traits in social insects, Annu. Rev. Entomol. 50, 395-420.

Buckland-Nicks J. (1998) Prosobranch parasperm: Sterile germ cells that promote paternity? Micron $29,267-280$.

Collins A.M. (2004) Sources of variation in the viability of honey bee, Apis mellifera L., semen collected for artificial insemination, Invertebr. Reprod. Dev. 45, 231-237.

Collins A.M., Donoghue A.M. (1999) Viability assessment of honey bee, Apis mellifera sperm using dual fluorescent staining, Theriogenology 51, 1513-1523.

Franck P., Coussy H., Le Conte Y., Solignac R., Garnery L., Cornuet J.M. (1999) Microsatellite analysis of sperm admixture in honeybee, Insect Mol. Biol. 8, 419-421.

Franck P., Solignac M., Vautrin D., Cornuet J.M., Koeniger G., Koeniger N. (2002) Sperm competition and last-male precedence in the honeybee, Anim. Behav. 64, 503-509.

Garcia-Gonzalez F., Simmons L.W. (2005) Sperm viability matters in insect sperm competition, Curr. Biol. 15, 271-275.

Haberl M., Tautz D. (1998) Sperm usage in honey bees, Behav. Ecol. Sociobiol. 42, 247-255.

Harbo J.R. (1990) Artificial mixing of spermatozoa from honeybees and evidence for sperm competition, J. Apic. Res. 29, 151-158.

Hunter F.M., Birkhead T.R. (2002) Sperm viability and sperm competition in insects, Curr. Biol. 12, 121123.

Jones J.C., Myerscough M.R., Graham S., Oldroyd B.P. (2004) Honey bee nest thermoregulation: Diversity promotes stability, Science 305,402 404.

Kerr W.E., Martinho M.R., Goncalves L.S. (1980) Kinship selection in bees, Rev. Bras. Genet. 3, 339-344.

Koeniger N., Koeniger G. (1991) An evolutionary approach to mating-behavior and drone copulatory organs in Apis, Apidologie 22, 581-590.

Kraus F.B., Neumann P., van Praagh J., Moritz R.F.A. (2004) Sperm limitation and the evolution of extreme polyandry in honeybees (Apis mellifera L.), Behav. Ecol. Sociobiol. 55, 494-501.

Laidlaw H., Page R. (1997) Queen rearing and bee breeding, Wicwas Press, Cheshire, CT.

Lodesani M., Balduzzi D., Galli A. (2004) A study on spermatozoa viability over time in honey bee (Apis mellifera ligustica) queen spermathecae, J. Apic. Res. 43, 27-28. 
Mattila H.R., Seeley T.D. (2007) Genetic diversity in honey bee colonies enhances productivity and fitness, Science 317, 362-364.

Moritz R.F.A. (1986) Intracolonial worker relationship and sperm competition in the honeybee (Apis mellifera L), Experientia 42, 445-448.

Palmer K.A., Oldroyd B.P. (2000) Evolution of multiple mating in the genus Apis, Apidologie 31, 235248.

Parker G.A. (1970) Sperm competition and its evolutionary consequences in insects, Biol. Rev. 45, 525-567.

Parker G.A. (1998) Sperm competition and the evolution of ejaculates: Towards a theory base, in: Birkhead T.R., Moller A.P. (Eds.), Sperm competition and sexual selection, Academic Press, London, pp. 3-54.

Pizzari T., Foster K.R. (2008) Sperm Sociality: Cooperation, Altruism, and Spite, PLoS Biol. 6, e130.

Price C.S.C., Dyer K.A., Coyne J.A. (1999) Sperm competition between Drosophila males involves both displacement and incapacitation, Nature 400, 449-452.

Schlüns H., Koeniger G., Koeniger N., Moritz R.F.A. (2004) Sperm utilization pattern in the honeybee (Apis mellifera), Behav. Ecol. Sociobiol. 56, 458463.

Seeley T.D., Tarpy D.R. (2007) Queen promiscuity lowers disease within honeybee colonies, Proc. R. Soc. B-Biol. Sci. 274, 67-72.
Silberglied R.E., Shepherd J.G., Dickinson J.L. (1984) Eunuchs - the role of apyrene sperm in Lepidoptera, Am. Nat. 123, 255-265.

Simmons L.W. (2001) Sperm competition and its evolutionary consequences in the insects, Princeton University Press, Princeton.

Snodgrass R.E. (1956) Anatomy of the honey bee, Comstock publishing associates, Ithaca.

Snook R.R. (2005) Sperm in competition: not playing by the numbers, Trends Ecol. Evol. 20, 46-53.

Tarpy D.R., Nielsen R., Nielsen D.I. (2004) A scientific note on the revised estimates of effective paternity frequency in Apis, Insectes Soc. 51, 203204.

Tarpy D.R., Seeley T.D. (2006) Lower disease infections in honeybee (Apis mellifera) colonies headed by polyandrous vs monandrous queens, Naturwissenschaften 93, 195-199.

Werner M., Simmons L.W. (2008) Insect sperm motility, Biol. Rev. 83, 191-208.

Williams J.L., Harbo J.R. (1982) Bioassay for diluents of honey bee semen, Ann. Entomol. Soc. Am. 75, 457-459.

Winston M. (1987) The Biology of the Honey Bee, Harvard University Press, Cambridge, MA.

Woyciechowski M., Krol E. (1996) On intraoviductal sperm competition in the honeybee (Apis mellifera), Folia Biologica-Krakow 44, 51-53.

Woyke J. (1983) Dynamics of entry of spermatozoa into the spermatheca of instrumentally inseminated queen honeybees, J. Apic. Res. 22, 150-154. 